\title{
Pomiar i określenie ugięcia powierzchni jeziorka spawalniczego oraz głębokości wtopienia spoiny w pulsacyjnym spawaniu MIG/MAG
}

\section{Measurement and estimation of weld pool surface depth and weld penetration in pulsed gas metal arc welding}

\section{Streszczenie}

Powierzchnia jeziorka spawalniczego może zawierać dane wystarczające do wyznaczenia głębokości wtopienia spoiny. W badaniach użyto szybkostrzelnego systemu wizyjnego z kamerą do rejestracji obrazu powierzchni jeziorka spawalniczego podczas spawania łukowego elektrodą topliwą w osłonie gazu (GMAW lub MIG/MAG). Aby wyliczyć ugięcie ciśnieniem łuku powierzchni jeziorka spawalniczego z uzyskanego obrazu zaproponowano procedurę kalibracji, która umożliwiłaby określenie parametrów do przeprowadzenia obliczeń. Ustalono parametry spawania do wykonania serii eksperymentów spawania prądem impulsowym metodą MIG/MAG. Modelowanie z użyciem danych eksperymentalnych wykazało, że zmiana ugięcia powierzchni jeziorka spawalniczego w fazie prądu impulsu może być wykorzystana do przewidywania głębokości wtopienia spoiny $z$ wystarczająca dokładnością. Bezpośrednie zastosowanie tych wyników komplikuje jednak konieczność wykorzystania systemu wizyjnego. Aby znaleźć metodę, którą można zastosować do monitorowania wtopienia spoiny przy użyciu sygnałów łatwych do zmierzenia w warunkach produkcyjnych, przeanalizowano potencjalny związek pomiędzy zmianą ugięcia powierzchni jeziorka spawalniczego a napięciem łuku. Analiza wykazała, że zmiana napięcia łuku w fazie prądu impulsu może precyzyjnie odzwierciedlać zmianę wartości ugięcia powierzchni jeziorka w fazie prądu impulsu. W związku z tym, proponuje się określanie wtopienia spoiny ze zmiany napięcia łuku w fazie prądu impulsu. Wyniki modelowania pokazują, że zmiana napięcia łuku w fazie prądu impulsu może umożliwiać dokładne przewidywanie głębokości wtopienia podczas spawania impulsowego MIG/MAG.

\section{Abstract}

The weld pool surface may contain sufficient information to determine weld penetration. In this study, a high-speed camera-based vision system was used to image the weld pool surface during gas metal arc welding (GMAW).To calculate the depth of the weld pool surface from the acquired image, a calibration procedure is proposed to determine the parameters in the calculation equation. Welding parameters were designed to conduct a series of pulsed GMAW (GMAW-P) experiments. Modeling using experimental data shows that the change of the weld pool surface depth during the peak current period can predict the depth of the weld penetration with adequate accuracy. However, a direct application of this result is complicated by the need for a vision system. To find a method that can be used to monitor the weld penetration using signals that are easily measurable in manufacturing facilities, a possible relationship between a change in weld pool surface depth and a change in arc voltage was analyzed. The analysis suggested that the change in arc voltage during the peak current period may reflect accurately the change in weld pool surface depth during the peak current period. As a result, it is proposed that the depth of the weld penetration be determined from the change in arc voltage during the peak current period. The modeling result shows that the change in arc voltage during peak current can indeed provide an accurate prediction for the depth of the weld penetration during GMAW-P

Z. Wang, Y., M. Zhang - University of Kentucky, Lexington, USA, L. Wu - Harbin Institute of Technology, Chiny. 


\section{Wstęp}

Spawanie łukowe elektrodą topliwą MIG/MAG (w Stanach Zjednoczonych GMAW) można uznać za najbardziej rozpowszechnioną metodę spawania, wybieraną ze względu na wszechstronność, prędkość i łatwość użycia w spawaniu zrobotyzowanym. $Z$ impulsowego spawania GMAW-P korzysta się w celu uzyskania kontrolowanego przenoszenia kropli metalu w szerokim zakresie poziomów wprowadzonego ciepła i masy [1, 2].

W metodzie tej niskie natężenie prądu (prąd bazy) utrzymuje łuk elektryczny, natomiast maksymalne natężenie prądu (prąd impulsu) służy do topienia drutu spawalniczego i odłączania powstałej kropli. W rezultacie - osiąga się pożądany mechanizm natryskowego przenoszenia kropli metalu przy niskiej średniej prądu $[3,4]$.

Wtopienie spoiny odgrywa zasadniczą rolę w określaniu jej wytrzymałości mechanicznej i wymiarowaniu spoin, toteż kontrola nad nim jest niezwykle istotna. Niniejszy artykuł dotyczy zastosowań z częściowym przetopem, w którym nie jest przetapiana cała grubość materiału spawanego. W przypadku spoin z niepełnym przetopieniem, głębokość szczeliny wypełniona stopiwem określa wymiar obliczeniowy spoiny. Głębokość ta jest często wykorzystywana do pomiaru wtopienia spoiny. Oczywiście oznacza to, że głębokość wtopienia spoiny nie jest bezpośrednio mierzalna i nie jest wliczana do wymiaru wytrzymałościowego spoiny, którą z konieczności jest głębokość rowka spawalniczego wypełnionego stopiwem. W celu jej określenia wprowadzono wiele metod opierających się na pomiarach pośrednich, takich jak: geometryczne parametry jeziorka spawalniczego [5] pole temperatury [6], częstotliwość drgań [7, 8] i napięcie łuku [9]. Aby uzyskać pomiary pośrednie, stosowano różnorodne techniki, takie jak: wizyjne [5, 10], ultradźwiękowe [11], emisji akustycznej [12] oraz termiczne [6]. Niemniej jednak większość tych wysiłków koncentrowała się na spawaniu łukowym elektrodą wolframową TIG (w Stanach Zjednoczonych GTAW).

Metoda TIG (GTAW) jest mniej skomplikowana i dużo bardziej stabilna w porównaniu z GMAW, na której skupiają się poniższe badania. W celu poprawy wydajności, w spawaniu GMAW jako elektrodę wykorzystuje się topliwy drut, a powstały w wyniku tego sposób przenoszenia kropli stopionego drutu komplikuje proces. Ze względu na przenoszenie ciekłego metalu, kropelki okresowo uderzają w ciekłe jeziorko i powodują jego drganie. W przypadku pulsacyjnego spawania GMAW, które jest przedmiotem obecnego badania, ciśnienie łuku również okresowo się zmienia, co powoduje dużą fluktuację powierzchni jeziorka. Wynikająca z tego złożoność przysporzyła dodatkowych trudności w uzyskaniu pośrednich pomiarów, koniecznych do określenia głębokości wtopienia spoiny. Spośród możliwych pomiarów pośrednich, mierzenie ugięcia powierzchni jeziorka spawalniczego wydaje się najbardziej obiecujące, dostarczając dostatecznej ilości danych koniecznych do oceny wtopienia spoiny. Wynika to $z$ tego, że wielu doświadczonych spawaczy potrafi kontrolować głębokość wtopienia spoiny tylko na podstawie obserwacji powierzchni jeziorka spawalniczego.

Zaproponowano metody pomiaru trójwymiarowej powierzchni jeziorka poprzez użycie oświetlenia strukturalnego i szkła rozpraszającego [13], oświetlenia strukturalnego i skalibrowanej kamery [14], odbicia zwierciadlanego od jeziorka $[15,16]$, kształtu z cieniowania [17], dwukamerowego, stereowizyjnego systemu [10] oraz systemu stereowizyjnego z bipryzmatem [18].

W innym badaniu Zhang i Yan zmierzyli średnią wysokość granicy brzegu jeziorka, tj. parametr dotyczący głębokości z modelu aproksymacji geometrycznej w spawaniu GMAW prądem impulsowym cienkich blach [19]. Niestety, metody te w znacznym stopniu opierają się na systemach wizyjnych, a ich użyteczność w warunkach produkcyjnych należy poprawić przed zastosowaniem w praktyce. W artykule przedstawiono opracowanie prostej, ale innowacyjnej metody, która pozwoli efektywnie uzyskać głębokość ugięcia powierzchni jeziorka spawalniczego pod łukiem elektrycznym (odtąd określaną jako głębokość ugięcia powierzchni jeziorka lub d) i porównuje się tę głębokość z głębokością wtopienia spoiny przez nią uzyskanego (odtąd głębokość wtopienia lub $\mathrm{d}_{\mathrm{w}}$ ). W celu zbadania związku pomiędzy nimi, głębokość ugięcia powierzchni jeziorka spawalniczego $d_{j}$ zmierzono bezpośrednio za pomocą widzenia maszynowego przez zastosowanie szybkostrzelnej kamery. Chcąc wykorzystać sygnały, które są łatwe do zmierzenia, żeby przewidzieć głębokość wtopienia $\mathrm{d}_{\mathrm{w}}$, mierzono również napięcie łuku elektrycznego w odniesieniu do głębokości wtopienia $\mathrm{d}_{\mathrm{w}}$.

\section{Zasada pomiaru z wykorzystaniem obrazowania}

Szybkostrzelna kamera, OLYMPUS i- SPEED, która jest w stanie uchwycić do 33000 klatek na sekundę i bezpośrednio rejestrować obraz jeziorka spawalniczego w obecności łuku, została umocowana $z$ górnej strony jeziorka spawalniczego pod kątem $\beta$ w celu obrazowania jeziorka, tak jak pokazano na rysunku 1. Uchwyt spawalniczy jest prostopadły do powierzchni elementu spawanego.

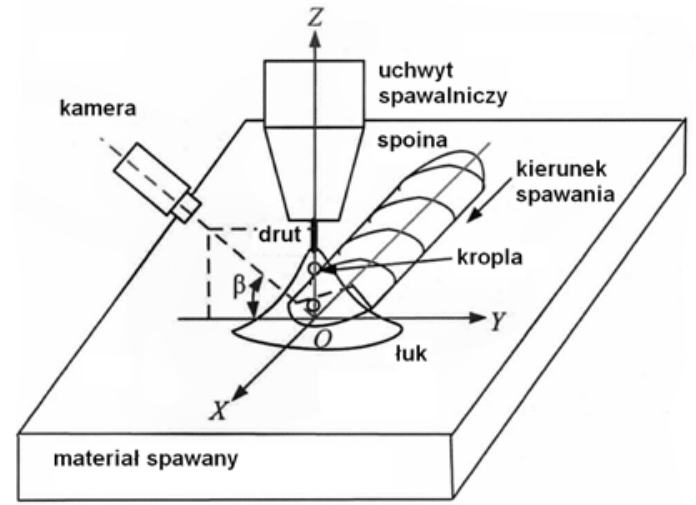

Rys. 1. Schemat pomiaru głębokości ugięcia powierzchni jeziorka spawalniczego

Fig. 1. Schematic diagram for SD measurement. 


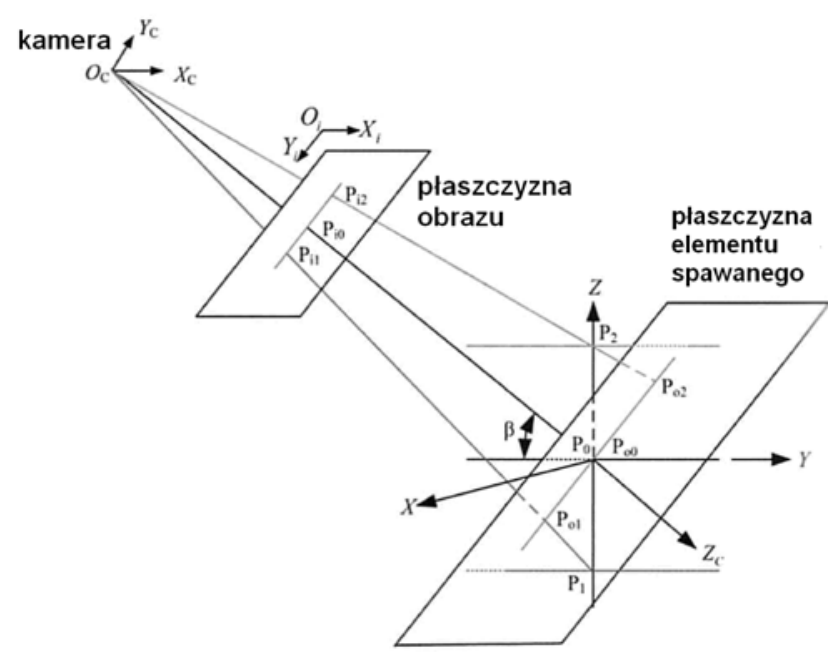

Rys. 2. Zasada pomiaru głębokości ugięcia powierzchni jeziorka spawalniczego

Fig. 2. The SD measurement principle

Dla wygody dyskusji naniesiony został układ współrzędnych OXYZ (rys. 1), przy czym górna powierzchnia elementu spawanego została przedstawiona jako płaszczyzna OXY; oś uchwytu spawalniczego odzwierciedla oś Z, a połączenie spawane i kierunek spawania - oś $X$.

Metodę pomiaru ugięcia powierzchni jeziorka spawalniczego $\mathrm{d}_{\mathrm{w}} \mathrm{w}$ oparciu o system wizyjny przedstawiono na rysunku 2.

Ugięcie powierzchni jeziorka spawalniczego d w tym artykule odnosi się do maksymalnej wartości ugięcia powierzchni jeziorka poniżej płaszczyzny OXY, którą można zmierzyć za pomocą współrzędnej osi Z: punktu przecięcia osi $Z$ i powierzchni jeziorka spawalniczego.

Wykorzystano model kamery otworkowej (wirująca tarcza z otworkiem chroni układ optyczny przed odpryskami spawalniczymi), (rys. 2). Zastosowano trzy układy współrzędnych: układ współrzędnych kamery $\left(\mathrm{O}_{C} \mathrm{X}_{\mathrm{C}} \mathrm{Y}_{\mathrm{C}} \mathrm{Z}_{\mathrm{c}}\right)$, układ współrzędnych obrazu $\left(\mathrm{O}_{\mathrm{i}} \mathrm{X}_{\mathrm{i}} \mathrm{Y}_{\mathrm{i}}\right)$ i układ współrzędnych uchwytu spawalniczego. Płaszczyzna obiektu jest równoległa do płaszczyzny obrazu i tworzy kąt $\beta$ z osią Z.

Kiedy powierzchnia jeziorka podnosi się tak, że punkt przecięcia się osi $Z$ z powierzchnią jeziorka spawalniczego podnosi się $z \mathrm{P}_{0}$ do $\mathrm{P}_{2}$, odpowiadający $\mathrm{mu}$ punkt na płaszczyźnie elementu zmienia się $\mathrm{z} \mathrm{P}_{\mathrm{oo}}$ na $P_{\text {o2 }}$, a odpowiadający im punkt na płaszczyźnie obrazu zmienia się $z \mathrm{P}_{\text {i0 }}$ na $\mathrm{P}_{\mathrm{i} 2}$ (rys,2). Głębokość ugięcia powierzchni jeziorka spawalniczego $d_{i}$ można zmierzyć zatem jako:

$$
d_{j}=-\left|P_{2} P_{0}\right|=-\left|P_{o 2} P_{o 0}\right| \cos \beta
$$

gdzie: $d_{j}$ oznacza wartość ugięcia powierzchni jeziorka spawalniczego, a ujemne/dodatnie $d_{j}$ odnosi się do powierzchni jeziorka spawalniczego powyżej/poniżej płaszczyzny OXY.

Podobnie, jeśli powierzchnia jeziorka spawalniczego się obniży, ugięcie jego powierzchni $\mathrm{d}_{\mathrm{j}}$ będzie następujące:

$$
d_{j}=\left|P_{o l} P_{o 0}\right| \cos \beta
$$

powiększenię $\mathrm{S}_{\mathrm{c}}$ definiujemy jako

$$
S_{c}=\left|P_{o j} P_{o o}\right| P_{i j} P_{i 0}
$$

gdzie: $P_{i j}$ jest punktem obrazu $P_{j}(j=1,2)$ na płaszczyźnie obrazu, podczas gdy $\mathrm{P}_{\mathrm{oj}}$ jest odpowiadającym mu punktem na płaszczyźnie elementu.

Wtedy:

$$
d_{j}= \pm S_{c} \times\left|P_{i j} P_{i 0}\right| \cos \beta
$$

Stąd:

$$
d_{j}=S_{c} \times\left(y_{i j}-y_{i 0}\right) / \cos \beta
$$

gdzie: $y_{i j}$ i $y_{i 0}$ są współrzędnymi y punktu $P_{i j}(j=1,2)$, a początek układu współrzędnych, odpowiednio, na obrazie.

Parametry powiększenie $S_{c}$ i kąt filmowania $\beta$ oraz pozycja początku układu współrzędnych na obrazie tj. $\mathrm{O}\left(\mathrm{x}_{\mathrm{i} 0}, \mathrm{y}_{\mathrm{i} 0}\right)$ są potrzebne do wyliczenia ugięcia powierzchni jeziorka spawalniczego $\mathrm{d}_{\mathrm{j}}$. W tym celu zastosowano kalibrację.

\section{Kalibracja}

Koło nie ma kierunkowości - korzystając z tej cechy koła opracowano procedurę kalibracji, aby określić $S_{c}$, $\beta$ oraz $\mathrm{O}\left(\mathrm{x}_{\mathrm{i},}, \mathrm{y}_{\mathrm{i} 0}\right)$. Koło kalibracji z krzyżykiem umieszczono tuż poniżej końcówki drutu i przyłożono do górnej powierzchni elementu spawanego (rys. 3).

Najlepiej byłoby, gdyby oś optyczna kamery nie tworzyła kąta z płaszczyzną OYZ, jednakże powinien istnieć niewielki kąt, oznaczony jako $\beta$, pomiędzy nimi wraz z niewielkim kątem obrotu $\theta$ (rys. 4). Wówczas obraz koła będzie elipsą, której dłuższa oś jest równa średnicy koła, a środek - środkiem koła.

Jeżeli parametry elipsy, włącznie z pozycją środka $\left(X_{0}, Y_{0}\right)$, półosią wielką a półosią małą $b$, oraz kątem obrotu elipsy $\alpha$, uzyskano $z$ przetwarzania obrazu,

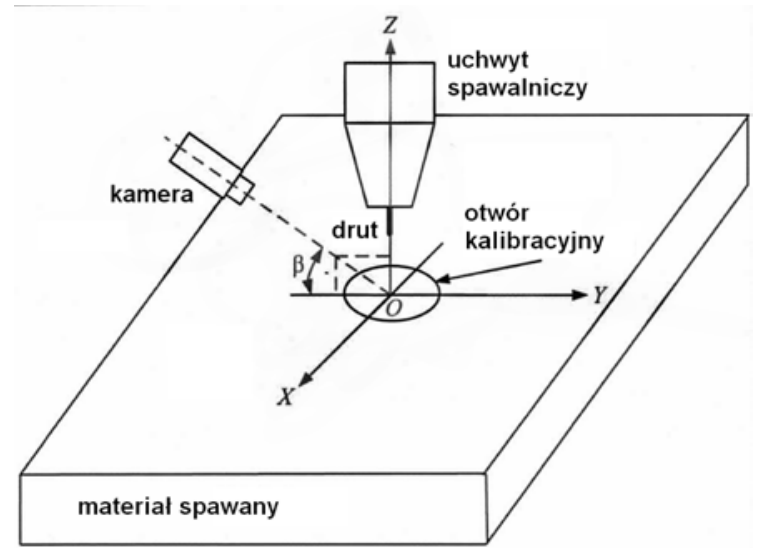

Rys. 3. Zasada kalibracji

Fig. 3. Calibration principle 


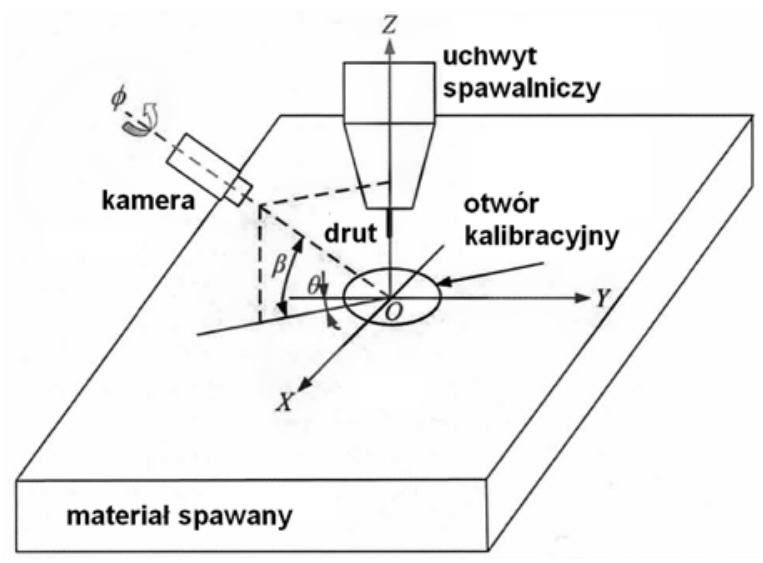

Rys. 4. Ilustracja położenia punktu obserwacji przy kalibracji Fig. 4. Illustration of observation orientation in calibration

można łatwo określić:

$$
\begin{gathered}
O=\left(X_{0}, Y_{0}\right) \\
\varphi=-\alpha \\
S_{c}=r / a
\end{gathered}
$$

gdzie: $r$ - rzeczywisty promień koła w mm,

a następnie

$$
\beta=\arcsin (b / a)
$$

Również nachylenia i przecięcia linii $k_{h}, b_{h}, k_{v}, b_{v}$ można uzyskać z przetwarzania obrazu. Definiujemy $\alpha^{\prime}=\arctan \left(k_{h}\right)$ i $\varphi=\alpha^{\prime}-\alpha$, a następnie

$$
\theta=\arcsin (\sin \varphi / \sin \beta)
$$

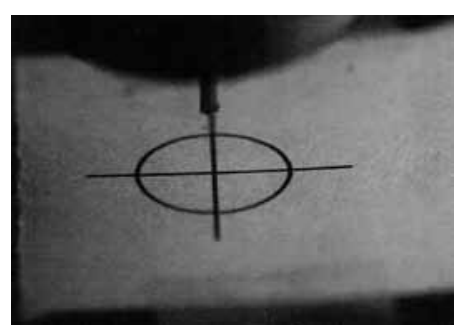

Rys. 5. Obraz koła kalibracj z krzyżykiem

Fig. 5. Image of the calibration circle with cross
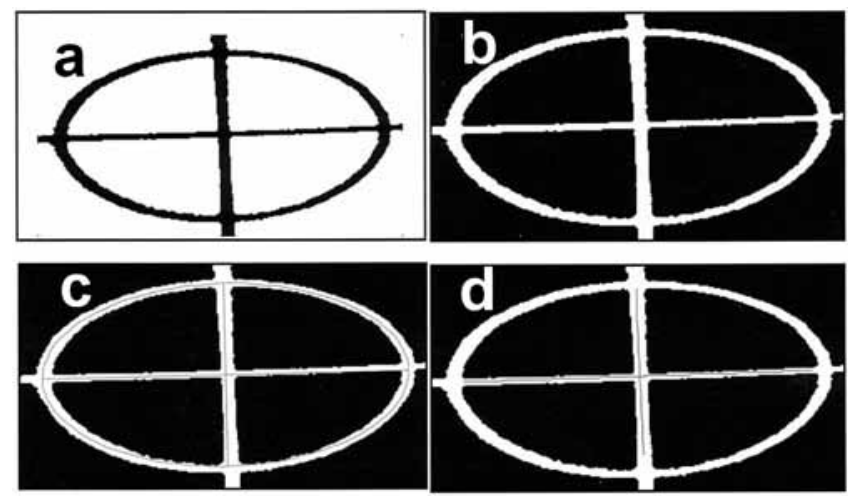

Rys. 6. Przetwarzanie obrazu i uzyskanie parametrów do kalibracji: a) binaryzacja; b) odwrócenie obrazu; c) dopasowanie elipsy; d) dopasowanie linii

Fig. 6. Image processing and parameters extraction for calibration: a) binarization; b) image inverting; c) ellipse fitting; d) lines fitting
Obraz koła kalibracji został pokazany na rysunku 5. Obszar, gdzie wybrano położenie koła kalibracji do przetwarzania, oraz wyniki przetwarzania obrazu pokazano na rysunku 6 . Parametry elipsy oraz linii łatwo uzyskać z przetwarzanego obrazu.

\section{Test algorytmu pomiaru i analiza błędu}

Zasady testu przedstawiono na rysunku 7. Przygotowano dwie metalowe blachy o identycznym rozmiarze, ale różnej grubości z identycznymi współosiowymi, okrągłymi otworami (1) z rysunku 7. Po ustawieniu kamery i blachy wzorcowej, płaszczyzna odniesienia, tj. górna powierzchnia blachy wzorcowej jest obrazowana tak, jak pokazano na (2). Następnie umieszcza się blachę testową na blasze wzorcowej tak, że ich otwory idealnie się pokrywają i są obrazowane (3). Te dwa obrazy są następnie przetwarzane w celu wykrycia punktów środkowych dwóch elips, które można wykorzystać do wyliczenia grubości blachy testowej. W badaniu obydwie blachy mają wymiary $100 \times 50 \mathrm{~mm}$, a ich grubości wynoszą: blachy wzorcowej $2,54 \mathrm{~mm}$ i blachy

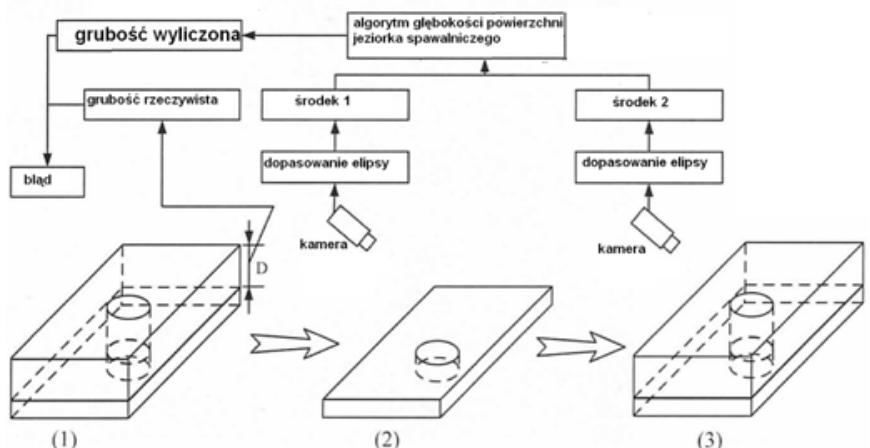

Rys. 7. Schemat testu algorytmu pomiaru

Fig. 7. Schematic diagram for measurement algorithm test

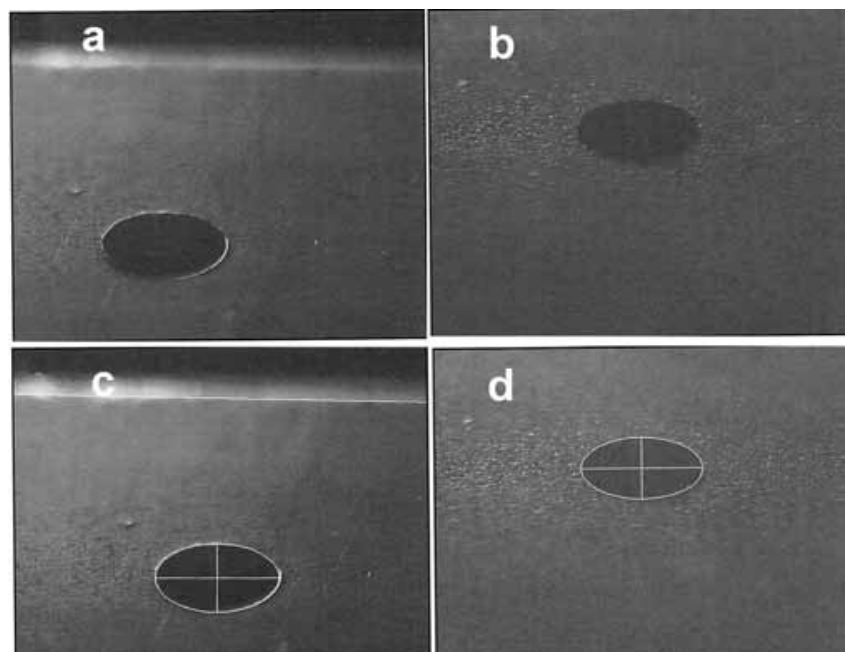

Rys. 8. Obrazy testu algorytmu pomiaru: a) płaszczyzna wzorcowa; b) płaszczyzna testowa; c) wynik dopasowania dla płaszczyzny wzorcowej; d) wynik dopasowania do płaszczyzny testowej

Fig. 8. Measurement algorithm test images: a) reference plane; b) test plane; c) fitting result for the reference plane; d) fitting result for the test plane 
Tablica I. Wynik testu algorytmu pomiaru

Table I. Measurement algorithm test result

\begin{tabular}{|c|c|c|}
\hline $\begin{array}{c}\text { Wyliczona } \\
\text { grubość, } \mathrm{mm}\end{array}$ & $\begin{array}{c}\text { Rzeczywista } \\
\text { grubość, } \mathrm{mm}\end{array}$ & $\begin{array}{c}\text { Błąd } \\
\text { względny, \% }\end{array}$ \\
\hline 6,72 & 6,35 & 5,76 \\
\hline
\end{tabular}

testowej $6,35 \mathrm{~mm}$. Średnica obydwu identycznych, okrągłych otworów wynosi $6,35 \mathrm{~mm}$. Dwa oryginalne obrazy pokazano na rysunkach $8 \mathrm{a}$ i $8 \mathrm{~b}$. Wyniki ustawienia elipsy i linii przedstawiono na rysunkach $8 \mathrm{c} \mathrm{i} \mathrm{8d.}$ Wyniki obliczeń grubości zawarto w tablicy I.

Jak wynika z tablicy I, wystąpił błąd obliczenia grubości w stosunku do grubości rzeczywistej, który można uznać za oszacowanie błędu dla zaproponowanego algorytmu obliczenia głębokości, kiedy powierzchnia jeziorka spawalniczego zmienia się na $6,35 \mathrm{~mm}$. Błąd ten pojawia się, ponieważ algorytm przedstawiony na rysunku 2. jest w rzeczywistości przybliżeniem dokładnego modelu kamery. Na rysunku 9 przedstawiono błąd |P'P"| spowodowany zastosowaniem przybliżenia, a więc nieodłączny błąd algorytmu obliczenia głębokości.

Względny błąd $\delta$ to:

$$
\begin{aligned}
\delta & =\left(\left|P P^{\prime \prime}\right|-\left|P P^{\prime}\right|\right) /\left|P P^{\prime}\right| \\
& =\frac{\cos \eta}{\cos (\beta-\eta) \cos \beta}-1
\end{aligned}
$$

Jak widać, jeżeli $\eta \rightarrow \beta$, to $\delta \rightarrow 0$. W powyższym przypadku, można wyliczyć zarówno $\beta$, jak i $\eta$ z równania (9), tj. $\beta=\arcsin (b / a)$ bazując na a i b z obrazu płyty wzorcowej oraz $\eta=\arcsin (b / a)$, używając a i b z obrazu płyty testowej, z czego wynika $\beta=0,576$, a $\eta=0,548$.

Względny nieodłączny błąd wynosi zatem 2,67\%. Są też inne źródła błędów, łącznie z możliwym niepożądanym samoistnym obrotem kamery, niewielką odległością pomiędzy dwoma blachami wykorzystanymi do testu, błąd obliczenia w wyliczaniu środków dwóch elips itd. Błąd podany w tablicy I jest pochodną wszystkich tych źródeł błędu. Jednakże w pomiarach zmiana wartość ugięcia powierzchni jeziorka spawalniczego jest znacznie mniejsza niż

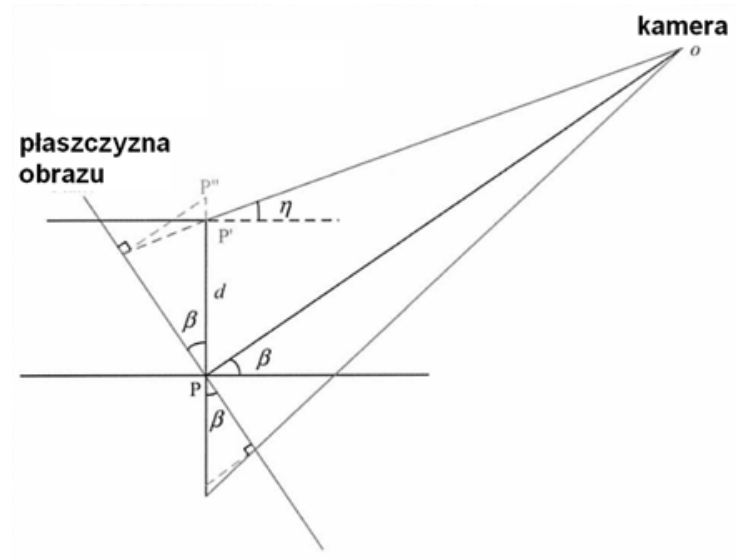

Rys. 9. Analiza błędu

Fig. 9. Error analysis
Tablica II. Obliczane parametry

\begin{tabular}{|c|c|}
\hline Parametry & Wartości \\
\hline Średni prąd spawania Ja, A & 192,0 \\
\hline Średnie napięcie prądu spawania $U_{a}, V$ & 30,4 \\
\hline $\begin{array}{l}\text { Średnie napięcie fazy maksymalnego natężenia } \\
\text { prądu } U_{p}, V\end{array}$ & 33,6 \\
\hline Średnie napięcie prądu bazy $U_{b}, V$ & 27,7 \\
\hline \multirow{5}{*}{$\begin{array}{l}\text { Zmiana napięcia prądu spawania } w \text { każdej fazie } \\
\text { maksymalnego natężenia prądu spaw. } \Delta U p i, V\end{array}$} & 3,83 \\
\hline & 2,13 \\
\hline & 0,75 \\
\hline & 3,33 \\
\hline & 1,38 \\
\hline \multirow{2}{*}{$\begin{array}{l}\text { Średnia zmiana napięcia prądu w każdej fazie maks. } \\
\text { natęż. prądu spaw. } \Delta U, V\end{array}$} & 2,28 \\
\hline & $-0,33$ \\
\hline $\begin{array}{l}\text { Średnie ugięcie powierzchni jeziorka w fazie maks. } \\
\text { natęż. prądu spaw. } d_{j}, m m\end{array}$ & 0,56 \\
\hline \multirow{4}{*}{$\begin{array}{l}\text { Zmiana ugięcia powierzchni jeziorka w każdej fazie } \\
\text { maks. natęż. prądu spaw. i } \Delta \mathrm{d}_{\mathrm{j}} \text {, mm }\end{array}$} & 0,52 \\
\hline & 1,01 \\
\hline & 0,56 \\
\hline & 0,38 \\
\hline $\begin{array}{l}\text { Średnia zmiana głębokości wtopienia w fazie maks. } \\
\text { natęż. prądu spaw. } \Delta \mathrm{d}_{\mathrm{j}} \text {, mm }\end{array}$ & 0,61 \\
\hline Szerokość spoiny Ws, mm & 6,57 \\
\hline Średnie wtopienie spoiny ds, $\mathrm{mm}$ & 2,63 \\
\hline
\end{tabular}

Table II. Calculated parameters list

6,35 mm użyte w powyższym teście, tak więc błąd spowodowany zastosowaniem przybliżonego modelu kamery jest bardzo ograniczony. Stąd też we właściwych pomiarach błąd będzie znacznie mniejszy niż $5,76 \%$, chociaż $5,76 \%$ należałoby uznać za dokładność wystarczającą dla kontroli wtopienia spoiny.

\section{Stanowisko badawcze}

Plan eksperymentu przedstawiono na rysunku 10. Źródło prądu jest ustawione w trybie prądu stałego (CC), a jego natężeniem steruje komputer docelowy za pomocą przetwornika C/A. Kamera Olympus i-Speed II rejestruje obrazy z prędkością 1000 klatek na sekundę $i$ zapisuje je na karcie pamięci. Napięciełuku i prąd rzeczywisty są synchronizowane $z$ obrazami, mierzone przez komputer docelowy i przechowywane w komputerze głównym (rys. 11).

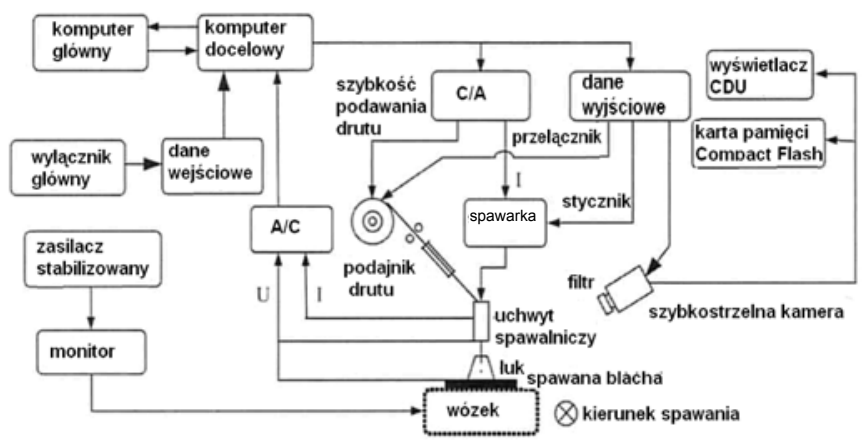

Rys. 10. Schemat aparatury badawczej

Fig. 10. Experimental setup 


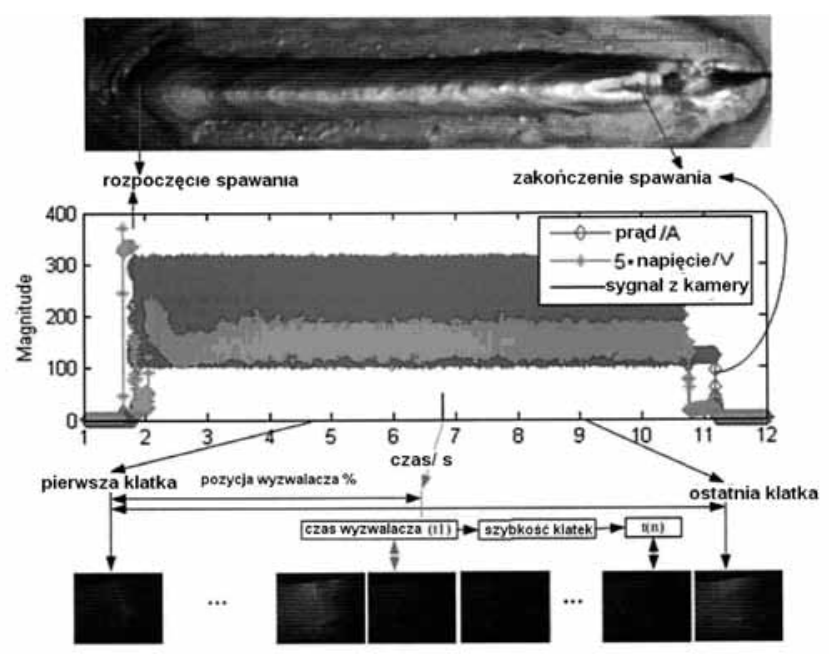

Rys. 11. Synchronizacja pomiarów

Fig. 11. Synchronization of measurements

\section{Pomiar głębokości ugięcia powierzchni jeziorka}

Przeprowadzono eksperyment, w którym mierzono ugięcie powierzchni jeziorka spawalniczego ugiętej pod łukiem. Dwa kawałki niskowęglowej stali o grubości $6,3 \mathrm{~mm}$ i wymiarach $300 \times 25,4 \mathrm{~mm}$ połączono w pozycji podolnej spoiną doczołową na I ze szczeliną $1,5 \mathrm{~mm}$. Uchwyt spawalniczy był ustawiony nieruchomo, a element spawany był przesuwany przez automat spawalniczy ze stałą prędkością $0,42 \mathrm{~m} / \mathrm{min}$. Odległość końcówki pradowej od elementu spawanego (CTWD) wynosiła $12 \mathrm{~mm}$. Użyto drutu z niskowęglowej stali ER70S-3 o średnicy $1,2 \mathrm{~mm}$. Prędkość podawania drutu $V_{d}$ wynosiła $4,8 \mathrm{~m} / \mathrm{min}$. Natężenie prądu impulsu wynosiło $300 \mathrm{~A}$, a prąd bazy $120 \mathrm{~A}$ (tabela III, próbka 13). Okres zmian prądu miał wartość 20,9 ms., a współczynnik wypełnienia $38,3 \%$. Gazem osłonowym był czysty argon, a natężenie przepływu gazu wynosiło 18,9 I/min. Obraz jeziorka spawalniczego uzyskany z kamery szybkostrzelnej przedstawiono na rysunku 12 . Środek powierzchni jeziorka spawalniczego zdefiniowano jako środek elipsy

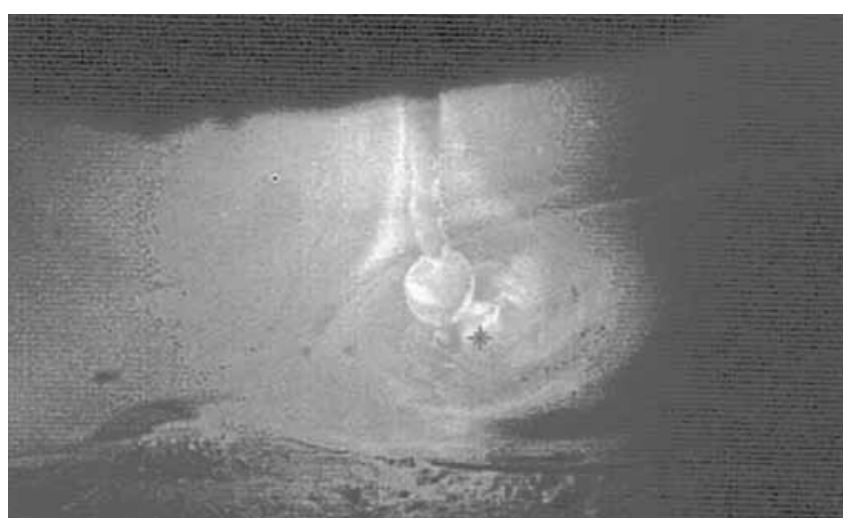

Rys. 12. Klatka filmu rejestrującego zmiany jeziorka z zaznaczonym środkiem jeziorka spawalniczego

Fig. 12. Weld pool image and weld pool surface center

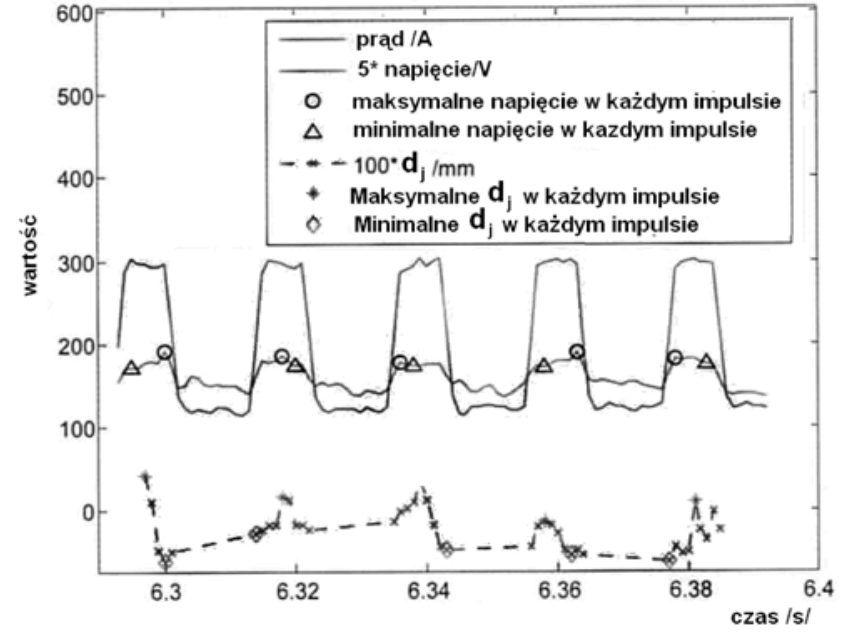

Rys. 13. Natężenie/napięcie prądu spawania i głębokości ugięcia jeziorka spawalniczego. Sygnały natężenia i napięcia prądu są średnimi obecnego i ostatniego poprzedniego punktu

Fig. 13. Welding current/voltage and SD. Current and voltage signals shown are averages of the measurements for the present and last previous point

jeziorka i oznaczono krzyżykowym punktem. Wykorzystując wcześniej opracowany algorytm, można wyliczyć głębokość ugięcia powierzchni jeziorka spawalniczego $d_{i} w$ fazie prądu impulsu i zsynchronizować z kształtem przebiegu prądu w czasie (rys. 13).

Można też wyliczyć średnią głębokość ugięcia powierzchni jeziorka spawalniczego $d_{j}$ :

$$
d_{j}=\left(\Sigma d_{j}\right) / k
$$

gdzie: $\mathrm{k}$ - liczba zastosowanych pomiarów $\mathrm{d}_{\mathrm{j}}$.

Ponieważ powierzchnia jeziorka spawalniczego drga ze względu na przenoszenie metalu, konieczne jest uśrednienie pomiarów. Pomiary ugięcia powierzchni jeziorka spawalniczego d $\mathrm{d}$ i-fazie prądu impulsu oznaczone zostają jako $\mathrm{d}_{\mathrm{ji}}$. Zmianę wartości ugięcia powierzchni jeziorka spawalniczego $d_{j} w$ i-fazie prądu impulsu przedstawia wzór:

$$
\Delta d_{j i}=\max \left(d_{j i}\right)-\min \left(d_{j i}\right)
$$

Średnia zmiana w różnych fazach maksymalnego natężenia prądu wynosi:

$$
\hat{L}_{j} d_{s}=\left(\sum_{i=1}^{n} \hat{A}_{j i} d_{s i}\right) / n
$$

gdzie: $\mathrm{n}$ - liczba rozważanych faz maksymalnego natężenia prądu.

W tablicy II umieszczono wszystkie powyższe pomiary eksperymentalne, wraz $z$ innymi zmiennymi i parametrami takimi jak: zmiana napięcia prądu i-fazie prądu impulsu $\Delta \mathrm{U}_{\mathrm{pi}}$ i średnia zmiana napięcia w różnych fazach prądu impulsu $\Delta U$ (zostanie omówiona później) szerokość spoiny $W_{i}$ i zmierzona przez szczelinę $z$ drugiej strony spoiny średnie wtopienie spoiny $d_{s}$. 


\section{Plan eksperymentu}

Gdy analizuje się metodę spawania GMAW, należy pamiętać, że na głębokość ugięcia powierzchni jeziorka $\left(d_{j}\right)$ i głębokość wtopienia spoiny $\left(d_{w}\right)$ mają wpływ nie tylko natężenie i napięcie prądu spawania, ale też prędkość podawania drutu $\mathrm{V}_{\mathrm{d}}$ i prędkość spawania $\mathrm{V}_{\mathrm{s}}$.

W przypadku, gdy wzrasta prędkość podawania drutu lub zmniejsza się prędkość spawania, głębokość wtopienia $d_{w}$ wzrasta.

Tablica III. Parametry spawania $\left(C=V_{d} / V_{s}=11,4\right)$

Table III. Welding parameters when $\left(C=V_{d} / V_{s}=11.4\right)$

\begin{tabular}{|c|c|c|c|c|c|c|c|}
\hline $\begin{array}{c}\mathrm{Nr} \\
\text { próby }\end{array}$ & $\begin{array}{c}\mathrm{V}_{\mathrm{s}} \\
\mathrm{m} / \mathrm{min})\end{array}$ & $\begin{array}{c}\mathrm{V}_{\mathrm{d}} \\
\mathrm{m} / \mathrm{min}\end{array}$ & $\begin{array}{c}\mathrm{I}_{\mathrm{a}} \\
\mathrm{A}\end{array}$ & $\begin{array}{c}\mathrm{Ip} \\
\mathrm{A}\end{array}$ & $\begin{array}{c}\mathrm{tp} \\
\mathrm{ms}\end{array}$ & $\begin{array}{c}\mathrm{Ib} \\
\mathrm{A}\end{array}$ & $\begin{array}{c}\mathrm{tb} \\
\mathrm{ms}\end{array}$ \\
\hline 11 & 0,30 & 3,43 & 135 & 300 & 8 & 70 & 20,3 \\
\hline 12 & 0,36 & 4,11 & 162 & 300 & 8 & 70 & 12 \\
\hline 13 & 0,42 & 4,80 & 189 & 300 & 8 & 120 & 12,9 \\
\hline 14 & 0,48 & 5,49 & 216 & 300 & 8 & 180 & 18,7 \\
\hline
\end{tabular}

$\mathrm{I}_{\mathrm{a}}$ - prąd średni, $\mathrm{I}_{\mathrm{p}}$ - prąd impulsi, $\mathrm{I}_{\mathrm{b}}$ - prąd bazy, $\mathrm{t}_{\mathrm{p}}$ - czas impulsu, $t_{b}-$ czas bazy

Tablica IV. Parametery spawania $\left(C=V_{d} / V_{s}=13,1\right)$

Table IV. Welding parameters when $\mathrm{C}=13.1$

\begin{tabular}{|c|c|c|c|c|c|c|c|}
\hline $\mathrm{Nr}$ & $\mathrm{V}_{\mathrm{s}}, \mathrm{m} / \mathrm{min}$ & $\mathrm{V}_{\mathrm{d}}, \mathrm{m} / \mathrm{min}$ & $\mathrm{I}_{\mathrm{a}}, \mathrm{A}$ & $\mathrm{I}_{\mathrm{p}}, \mathrm{A}$ & $\mathrm{t}_{\mathrm{p}}, \mathrm{ms}$ & $\mathrm{I}_{\mathrm{b}}, \mathrm{A}$ & $\mathrm{t}_{\mathrm{b}}, \mathrm{ms}$ \\
\hline 21 & 0,30 & 3,94 & 155 & 300 & 8 & 70 & 13,6 \\
\hline 22 & 0,36 & 4,72 & 186 & 300 & 8 & 70 & 7,9 \\
\hline 23 & 0,42 & 5,51 & 217 & 300 & 8 & 120 & 6,8 \\
\hline 24 & 0,48 & 6,30 & 248 & 300 & 8 & 180 & 6,1 \\
\hline
\end{tabular}

Tablica V. Parametery spawania $\left(C=V_{d} / V_{s}=14,8\right)$

Table V. Welding parameters when $\mathrm{C}=14.8$

\begin{tabular}{|c|c|c|c|c|c|c|c|}
\hline $\mathrm{Nr}$ & $\mathrm{V}_{s}, \mathrm{~m} / \mathrm{min}$ & $\mathrm{V}_{\mathrm{d}}, \mathrm{m} / \mathrm{min}$ & $\mathrm{I}_{\mathrm{a}}, \mathrm{A}$ & $\mathrm{I}_{\mathrm{p}}, \mathrm{A}$ & $\mathrm{t}_{\mathrm{p}}, \mathrm{ms}$ & $\mathrm{I}_{\mathrm{b}}, \mathrm{A}$ & $\mathrm{t}_{\mathrm{b}}, \mathrm{ms}$ \\
\hline 31 & 0,30 & 4,45 & 175 & 300 & 8 & 70 & 9,5 \\
\hline 32 & 0,36 & 5,33 & 210 & 300 & 8 & 70 & 5,1 \\
\hline 33 & 0,42 & 6,22 & 245 & 300 & 8 & 120 & 3,5 \\
\hline 34 & 0,48 & 7,11 & 280 & 300 & 8 & 180 & 1,6 \\
\hline
\end{tabular}

Tablica VI. Parametery spawania $\left(\mathrm{C}=\mathrm{V}_{\mathrm{d}} / \mathrm{V}_{\mathrm{s}}=16,5\right)$

Table VI. Welding parameters when $\mathrm{C}=16.5$

\begin{tabular}{|c|c|c|c|c|c|c|c|}
\hline $\mathrm{Nr}$ & $\mathrm{V}_{\mathrm{s}}, \mathrm{m} / \mathrm{min}$ & $\mathrm{V}_{\mathrm{d}}, \mathrm{m} / \mathrm{min}$ & $\mathrm{I}_{\mathrm{a}}, \mathrm{A}$ & $\mathrm{I}_{\mathrm{p}}, \mathrm{A}$ & $\mathrm{t}_{\mathrm{p}}, \mathrm{ms}$ & $\mathrm{I}_{\mathrm{b}}, \mathrm{A}$ & $\mathrm{t}_{\mathrm{b}}, \mathrm{ms}$ \\
\hline 41 & 0,30 & 4,95 & 195 & 300 & 8 & 70 & 6,7 \\
\hline 42 & 0,36 & 5,94 & 234 & 300 & 8 & 70 & 3,2 \\
\hline 43 & 0,42 & 6,93 & 273 & 300 & 8 & 120 & 1,4 \\
\hline 44 & 0,48 & 7,92 & 312 & 324 & 8 & 300 & 8 \\
\hline
\end{tabular}

Tablica VII. Parametry spawania $\left(\mathrm{C}=\mathrm{V}_{d} / \mathrm{V}_{\mathrm{s}}=18,2\right)$

Table VII. Welding parameters when $\mathrm{C}=18.2$

\begin{tabular}{|c|c|c|c|c|c|c|c|}
\hline $\mathrm{Nr}$ & $\mathrm{V}_{\mathrm{s}}, \mathrm{m} / \mathrm{min}$ & $\mathrm{V}_{\mathrm{d}}, \mathrm{m} / \mathrm{min}$ & $\mathrm{I}_{\mathrm{a}}, \mathrm{A}$ & $\mathrm{I}_{\mathrm{p}}, \mathrm{A}$ & $\mathrm{t}_{\mathrm{p}}, \mathrm{ms}$ & $\mathrm{I}_{\mathrm{b}}, \mathrm{A}$ & $\mathrm{t}_{\mathrm{b}}, \mathrm{ms}$ \\
\hline 51 & 0,30 & 5,46 & 215 & 300 & 8 & 70 & 4,7 \\
\hline 52 & 0,36 & 6,55 & 258 & 300 & 8 & 70 & 1,8 \\
\hline 53 & 0,42 & 7,65 & 301 & 302 & 8 & 300 & 8 \\
\hline 54 & 0,48 & 8,74 & 344 & 388 & 8 & 300 & 8 \\
\hline
\end{tabular}

Aby skupić się w tym badaniu na wpływie natężenia/napięcia prądu, odkładanie metalu można początkowo kontrolować za pomocą współczynnika:

$$
C=V_{d} / V_{s}
$$

Aby zbadać wpływ odkładania metalu na ugięcie powierzchni jeziorka spawalniczego d i głębokość wtopienia $\mathrm{d}_{w}$ można zmieniać ten współczynnik.

Planując eksperyment wstępnie dobrano typową dla spawania GMAW prędkość spawania $V_{s} z$ zakresu $0,3 \mathrm{~m} / \mathrm{min} \div 0,48 \mathrm{~m} / \mathrm{min}$. Następnie na podstawie $\mathrm{C}=\mathrm{V}_{\mathrm{d}} / \mathrm{V}_{\mathrm{s}}$ określono prędkość podawania drutu $\mathrm{V}_{\mathrm{d}}$. Wartość średniego natężenia prądu spawania ustalono $w$ przybliżeniu dla prędkości podawania drutu i użyto jej jako ograniczenia przy doborze kształtu przebiegu prądu pulsacyjnego. Aby ułatwić pomiar ugięcia powierzchni jeziorka spawalniczego $d$ w warunkach produkcyjnych za pomocą zmian napięcia łuku spawalniczego U należało również rozwiązać problem wpływu natężenia prądu na związek pomiędzy długością łuku a napięciem łuku.

Tak więc, natężenie prądu impulsu i okres trwania impulsu są wcześniej ustalonymi stałymi, a prąd bazy i czas trwania prądu bazy określa się na podstawie średniego prądu.

W tym badaniu zastosowano maksymalną wartość natężenia łuku $300 \mathrm{~A}$ i czas impulsu $8 \mathrm{~ms}$. Ustalone parametry spawania dla serii eksperymentów z pięcioma wartościami $\mathrm{C}=\mathrm{V}_{\mathrm{d}} / \mathrm{V}_{\mathrm{s}}$ przedstawiono $\mathrm{w}$ tablicach III $\div \mathrm{VII}$

\section{Wyniki eksperymentu i dyskusja}

W tablicy VIII przedstawiono wyniki pięciu serii eksperymentów przeprowadzonych z wykorzystaniem parametrów spawania przedstawionych $\mathrm{w}$ tablicach III $\div$ VII. Stosunek prędkości podawania drutu do prędkości spawania $V_{d} / V_{s}$ jest stałą, średnie natężenie prądu wzrasta, średnia zmiana głębokość ugięcia powierzchni jeziorka spawalniczego $d_{j} w$ fazie maksymalnego natężenia prądu spada, a wartości wtopienia $\mathrm{d}_{\mathrm{w}}$ wzrasta. Na rysunku 14 dla przykładowej wartości

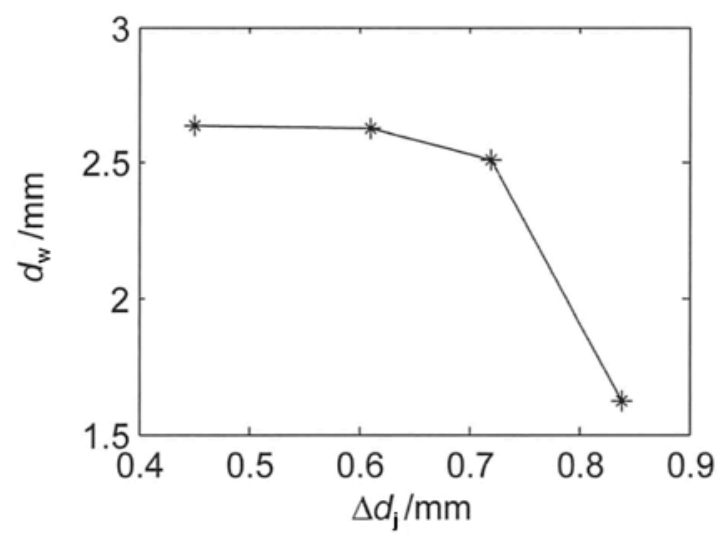

Rys. 14. Zależność głębokości wtopienia spoiny dw od przyrostu ugięcia jeziorka $\Delta \mathrm{d}_{\mathrm{j}}\left(\mathrm{C}=\mathrm{V}_{\mathrm{d}} / \mathrm{V}_{\mathrm{s}}=11,4\right)$

Fig. 14. Relationship between Äds and weld penetration when $C=11.4$ 
Tablica VIII. Wyniki eksperymentu modelowania

Table VIII. Experimental Results for Modeling

\begin{tabular}{|c|c|c|c|c|c|c|c|c|c|c|}
\hline \multirow{2}{*}{$\begin{array}{c}\mathrm{Nr} \\
\text { próby }\end{array}$} & \multirow{2}{*}{$\begin{array}{l}C \\
-\end{array}$} & \multirow{2}{*}{$\frac{\mathrm{I}_{\mathrm{a}}, \mathrm{A}}{\mathrm{d}_{\mathrm{w}}}$} & \multicolumn{3}{|c|}{$\mathrm{U}, \mathrm{V}$} & \multirow{2}{*}{$\frac{\mathrm{d}_{\mathrm{j}}}{\mathrm{mm}}$} & \multirow{2}{*}{$\frac{\Delta \mathrm{d}_{\mathrm{j}}}{\mathrm{mm}}$} & \multirow{2}{*}{$\frac{\Delta \mathrm{U}}{\mathrm{V}}$} & \multirow{2}{*}{$\frac{\mathrm{W}_{\mathrm{s}}}{\mathrm{mm}}$} & \multirow{2}{*}{$\frac{\mathrm{d}_{\mathrm{w}}}{\mathrm{mm}}$} \\
\hline & & & $U_{a}$ & $U_{p}$ & $U_{b}$ & & & & & \\
\hline 11 & 11,4 & 136,8 & 26,4 & 31,3 & 22,4 & 0,45 & 0,84 & 3,59 & 6,38 & 1,62 \\
\hline 12 & 11,4 & 158,6 & 28,2 & 32,4 & 24,4 & 0,28 & 0,72 & 2,46 & 6,70 & 2,51 \\
\hline 13 & 11,4 & 192,0 & 30,4 & 33,6 & 27,7 & $-0,33$ & 0,61 & 2,28 & 6,57 & 2,63 \\
\hline 14 & 11,4 & 218,1 & 31,3 & 33,8 & 29,7 & $-0,16$ & 0,45 & 1,93 & 5,61 & 2,64 \\
\hline 21 & 13,1 & 154,1 & 27,9 & 31,9 & 23,8 & 0,33 & 0,68 & 3,19 & 7,85 & 1,93 \\
\hline 22 & 13,1 & 182,1 & 30,1 & 34,1 & 25,7 & 0,16 & 0,49 & 1,65 & 6,87 & 2,58 \\
\hline 23 & 13,1 & 212,1 & 30,4 & 33,4 & 27,1 & $-0,17$ & 0,44 & 1,16 & 8,90 & 3,01 \\
\hline 24 & 13,1 & 246,4 & 32,7 & 34,4 & 30,6 & $-0,31$ & 0,41 & 1,05 & 6,59 & 3,23 \\
\hline 31 & 14,8 & 176,4 & 30,1 & 34,1 & 26,4 & 0,31 & 0,57 & 2,23 & 8,17 & 2,45 \\
\hline 32 & 14,8 & 211,4 & 31,7 & 35,2 & 27,6 & 0,05 & 0,43 & 1,28 & 8,81 & 2,83 \\
\hline 33 & 14,8 & 243,6 & 32,0 & 34,2 & 28,8 & 0,04 & 0,40 & 0,99 & 11,13 & 3,27 \\
\hline 34 & 14,8 & 275,9 & 34,8 & 35,9 & 33,4 & 0,69 & 0,38 & 0,76 & 7,88 & 3,31 \\
\hline 41 & 16,5 & 192,4 & 30,7 & 34,3 & 26,6 & 0,15 & 0,42 & 1,82 & 8,66 & 2,60 \\
\hline 42 & 16,5 & 230,1 & 32,5 & 34,8 & 28,8 & 0,02 & 0,37 & 1,22 & 10,83 & 3,27 \\
\hline 43 & 16,5 & 271,7 & 34,5 & 35,5 & 32,4 & 0,30 & 0,33 & 0,81 & 8,98 & 3,33 \\
\hline 44 & 16,5 & 308,2 & 35,6 & 36,2 & 35,0 & 1,00 & 0,17 & 0,74 & 8,55 & 3,45 \\
\hline 51 & 18,2 & 211,1 & 31,5 & 34,6 & 27,6 & $-0,43$ & 0,39 & 1,73 & 11,54 & 2,93 \\
\hline 52 & 18,2 & 254,8 & 33,4 & 34,9 & 30,2 & $-0,01$ & 0,30 & 1,06 & 9,17 & 3,74 \\
\hline 53 & 18,2 & 298,3 & 35,1 & 35,6 & 34,5 & 0,33 & 0,24 & 0,79 & 14,69 & 4,09 \\
\hline 54 & 18,2 & 334,9 & 37,1 & 38,4 & 35,7 & 1,05 & 0,16 & 0,94 & 7,41 & 4,35 \\
\hline
\end{tabular}

gdzie: $d_{j}$ - głębokość ugięcia powierzchni jeziorka spawalniczego, $d_{w}$ - głębokość wtopienia, $W_{s}-s$ szerokość spoiny, $\Delta$ d - przyrost głębokości ugięcia jeziorka spawalniczego, $\Delta \mathrm{U}$ - przyrost napięcia w fazie prądu impulsu, $\mathrm{C}=\mathrm{V}_{\mathrm{d}} / \mathrm{V}_{\mathrm{s}}-\mathrm{stosunek}_{\mathrm{s}}$ prędkości podawania drutu do prędkości spawania, $U_{a}$ - średnie napięcie, $U_{p}$ - impulsu napięcie, $U_{b}$ - napięcie bazy

współczynnika odkładania metalu $\mathrm{C}=\mathrm{V}_{\mathrm{d}} / \mathrm{V}_{\mathrm{s}}=11,4$, pokazano związek pomiędzy średnią zmianą ugięcia powierzchni jeziorka spawalniczego $d_{j} w$ fazach prądu impulsu i głębokości wtopienia $\mathrm{d}_{\mathrm{w}}$.

$Z$ analizy metody spawania impulsowego GMAW-P wynika, że jeżeli nie bierze się pod uwagę uderzania kropli metalu, to przód jeziorka spawalniczego jest uginany przez ciśnienie łuku spawalniczego, a stopiony metal wypływa przy końcu jeziorka spawalniczego w fazie prądu impulsu (rys. 15 a, b). Jak pokazano na rysunku $15 \mathrm{c}, \mathrm{w}$ fazie prądu bazy stopiony metal z powodu spadku ciśnienia łuku znowu wpływa na początek jeziorka, a jego powierzchnia podnosi się. Kiedy odkładanie metalu $\mathrm{C}$ pozostaje niezmienne, głębokość wtopienia $d_{w}$ wzrośnie gdy w wyniku wzrostu ugięcia powierzchni jeziorka spawalniczego $d_{\mathrm{j}}$ wzrośnie długość łuku (rys. 15b).

$Z$ innego punktu widzenia - ponieważ prąd impulsu i długość trwania tej fazy są utrzymywane na stałym poziomie, jeżeli wzrasta wtopienie spoiny, musi ono być spowodowane albo wzrostem natężenia prądu bazy, albo skróceniem okresu prądu bazy. Według rysunku $15 \mathrm{~d}$ wtopienie będzie większe gdy na skutek wzrostu w fazie prądu bazy wzrośnie ciśnienie łuku, lub jeżeli mniej metalu podpłynie z powrotem pod koniec trwania okresu prądu bazy, gdy ciekły metal będzie miał mniej czasu na spłynięcie na skutek skrócenia okresu trwania prądu bazy. Co więcej, możliwe jest, że powierzchnia jeziorka spawalniczego zostanie zepchnięta na ten sam poziom z powodu niezmienionych wartości maksymalnego natężenia prądu i długości tej fazy. Stąd też zmiana głębokości ugięcia powierzchni jeziorka spawalniczego $d_{d} w$ fazie maksymalnego natężenia prądu spadałaby tak, jak zaobserwowano w tablicy VIII i na rysunku 14.

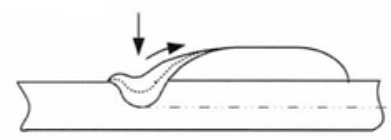

c)

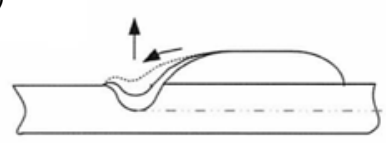

b)

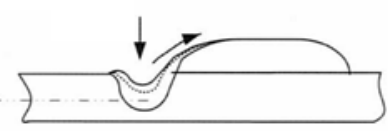

d)

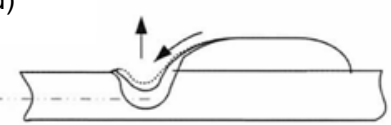

Rys. 15. Zmiana głębokości ugięcia powierzchni jeziorka spawalniczego $\Delta \mathrm{d}_{\mathrm{j}}$, a) faza maksymalnego natężenia prądu; b) faza maksymalnego natężenia prądu przy większym wtopieniu; c) faza prądu bazy; d) faza prądu bazy przy głębszym wtopieniu,

Fig. 15 - Different penetrations Äds. a) Peak period; b) peak period in deeper penetration; c) base period; d) base period in deeper penetration. 
Gdy weźmie się pod uwagę uderzenia kropli metalu, zmiana wartość ugięcia powierzchni jeziorka spawalniczego $d_{j} w$ fazie prądu impulsu powinna się zmienić.

Jednakże prąd impulsu i długość fazy są podczas eksperymentów niezmienne. Wpływ uderzenia kropli na zmianę ugięcia powierzchni jeziorka spawalniczego $d_{i}$ należy uznać za niezmienny przy każdym eksperymencie. Toteż kiedy stosunek prędkości podawania drutu do prędkości spawania $\mathrm{V}_{\mathrm{d}} / \mathrm{V}_{\mathrm{s}}$ jest stały $\mathrm{w}$ metodzie spawania GMAW-P kropla nie powinna modyfikować tego, jak średnia zmiana ugięcia powierzchni jeziorka spawalniczego $d_{j} w$ fazie prądu impulsu jest związana z wtopieniem spoiny.

Biorąc pod uwage stosunek $V_{d} / V_{s}$, wtopienie spoiny jest funkcję ugięcia jeziorka spawalniczego $\Delta d$ $\mathrm{i}_{\mathrm{d}} / \mathrm{V}_{\mathrm{s}}$ :

$$
d_{w}=f\left(\Delta d_{j}, V_{d} / V_{s}\right)
$$

Po wstawieniu danych można uzyskać przedstawiony na rysunku 16 a nieparametryczny model graficzny dla tego związku. Jak można zauważyć, powierzchnia na rysunku 16a jest bliska płaszczyźnie. Stąd, przy standardowym odchyleniu 0,27 mm można dopasować model płaszczyzny:

$$
d_{w}=-3,34 \times \Delta d_{j}+0,01 \times V_{d} / V_{s}+4,31
$$

Dopasowanie płaszczyzny do wstawionych danych przedstawiono na rysunku 16b. Liniowy model płaszczyzny jest wystarczająco dokładny dla potrzeb kontroli wtopienia spoiny w metodzie spawania GMAW-P Analiza wzoru (17) pokazuje, że drugi człon równania z stosunkiem prędkości podawania drutu do prędkości spawania $V_{d} / V_{s} w$ niewielkim stopniu wpływa na wtopienie spoiny. Dlatego też możliwe jest uproszczenie modelu, bez uwzględnienia stosunku prędkości podawania drutu do prędkości spawania $\mathrm{V}_{\mathrm{d}} / \mathrm{V}_{\mathrm{s}}$.

a)
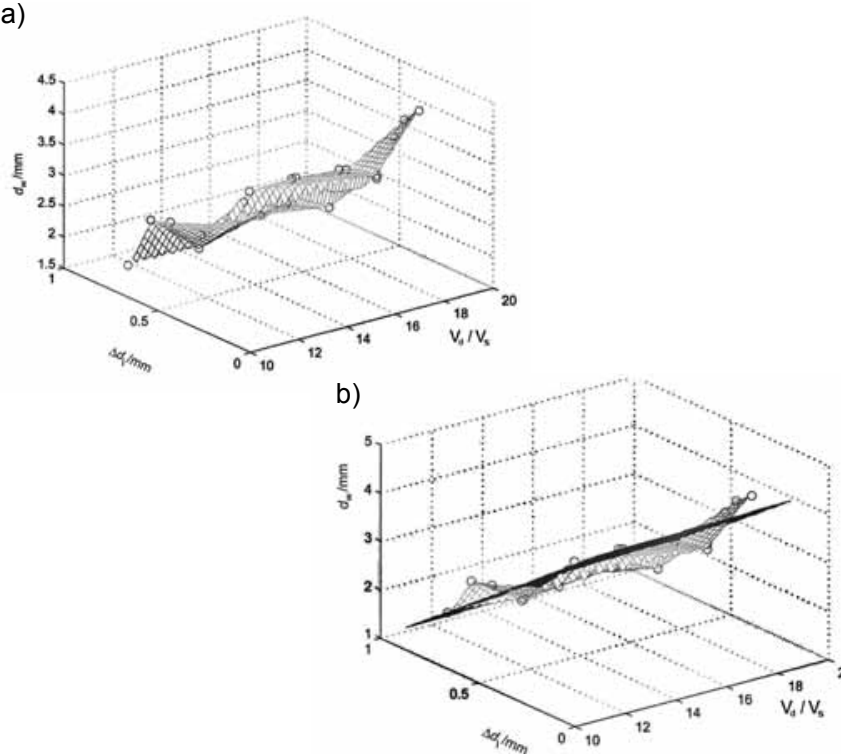

Rys. 16. Modelowanie, a) nieparametryczny model graficzny; b) model płaszczyzny,

Fig. 16. Modeling. a) nonparametric graphic model; b) plane model.
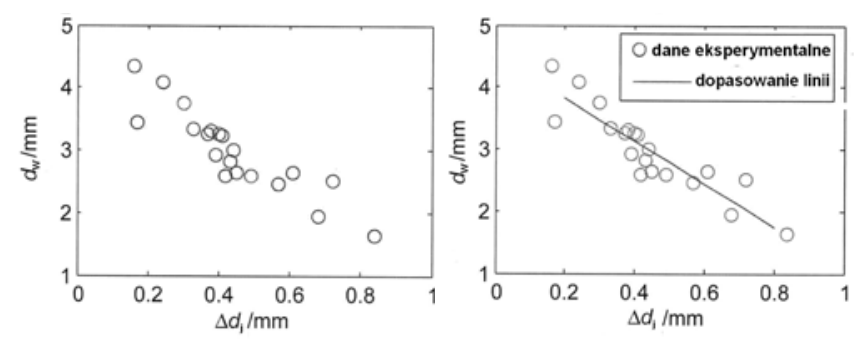

Rys. 17. Modelowanie bez $\mathrm{V}_{\mathrm{d}} / \mathrm{V}_{\mathrm{s}}$, a) zależność wtopienia $\mathrm{d}_{\mathrm{w}}$ od $\Delta \mathrm{d}_{\mathrm{j}}$, b) dopasowanie linii

Fig. 17. Modeling without WFS/TS: a) Äds vs. penetration; b) line fitting

Wyniki dopasowania lini prostej $z$ rysunku $17 \mathrm{~b}$ przy stałym odchyleniu 0,27 mm można przedstawić w postaci wzoru:

$$
d_{w}=-3,45 \times \Delta d_{j}+4,51
$$

Dokładność zależy od dokładności modelu płaszczyzny. Zatem na tej podstawie i zmiany głębokości jeziorka spawalniczego $\mathrm{w}$ fazie maksymalnego natężenia prądu można $z$ dostateczną dokładnością przewidzieć głębokość wtopienia spoiny.

\section{Modelowanie w zastosowaniu praktycznym}

Rezultat świadczący o tym, że wtopienie spoiny można przewidzieć na podstawie zmiany głębokości powierzchni jeziorka spawalniczego $\mathrm{w}$ fazie prądu impulsu, jest fundamentalny, ale jego bezpośrednie zastosowanie do kontroli wtopienia w warunkach produkcyjnych może być skomplikowane, zwłaszcza jeśli ugięcia powierzchni jeziorka spawalniczego mierzy się metodą widzenia maszynowego.

Ponieważ zmiana ugięcia powierzchni jeziorka spawalniczego powoduje zmianę długości łuku, którą można zmierzyć z napięcia łuku, to aby znaleźć metodę monitorowania wtopienia spoiny za pomocą sygnałów, które łatwo zmierzyć w zakładach produkcyjnych, rozważano związek pomiędzy zmianą ugięcia powierzchni jeziorka spawalniczego a zmianą napięcia łuku. W fazie prądu impulsu prąd jest stały i tylko napięcie łuku określa długość. Stąd też możliwe jest, że zmiana napięcia łuku w fazie prądu impulsu może odzwierciedlać zmianę wartości ugięcia powierzchni jeziorka spawalniczego.

Dla badań ilościowych zdefiniujmy podobnie zmianę napięcia w i-tej fazie prądu impulsu jako:

$$
\Delta U_{p i}=\max \left(U_{p i}\right)-\min \left(U_{p i}\right)
$$

a średnią zmianę w różnych fazach prądu impulsu jako:

$$
\Delta U=\left(\sum_{i=1}^{n} \Delta U_{p i}\right) / n
$$


$Z$ danych eksperymentalnych, przedstawionych w tablicy VIII, uzyskano rysunek 18 . Widać, tak jak oczekiwano, że istnieje duża korelacja pomiędzy przyrostem napięcia w fazie prądu impulsu $\Delta U$ i przyrostem ugięcia jeziorka spawalniczego $\Delta \mathrm{d}_{\mathrm{d}}, \mathrm{Z}$ łatwością można je powiązać. Używając przyrostu napięcia w fazie prądu impulsu $\Delta \mathrm{U}$, zamiast przyrostu ugięcia jeziorka spawalniczego $\Delta$ ds, przyjęto następujące równanie:

$$
d_{w}=-0,56 \times \Delta U+0,08 \times V_{d} / V_{s}+2.69
$$

Standardowe odchylenie wynosi $0,27 \mathrm{~mm}$ i jest takie samo, jak w równaniu (17). Co więcej, na podstawie danych eksperymentalnych z tablicy VIII równanie to można uprościć do postaci liniowej:

$$
d_{w}=-0,71 \times \Delta U+4,12
$$

Jego standardowe odchylenie wynosi $0,31 \mathrm{~mm}$, nieco więcej niż przy użyciu $\Delta U$, a stosunek prędkości podawania drutu do prędkości spawania $C=V_{d} / V_{s}$.

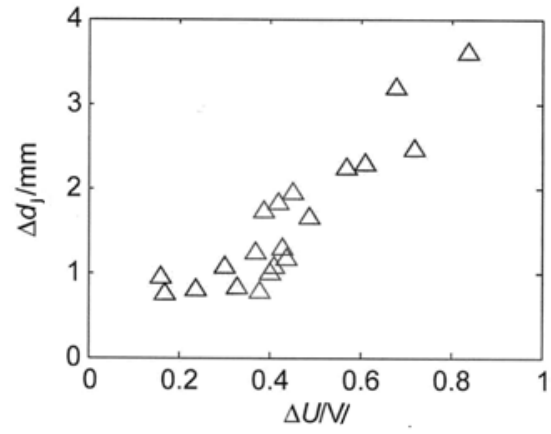

Rys. 18. Zależność głębokości ugięcia jeziorka spawalniczego $\Delta d$ od zmiany napięcia w fazie prądu impulsu $\Delta U$

Fig. 18. $\Delta \mathrm{U}$ vs. $\Delta \mathrm{d}_{\mathrm{i}}\left(\Delta \mathrm{d}_{\mathrm{s}}\right)$

Dla sterowania wtopienia spoiny można to równanie uznać za równie efektywne jak równanie (21). Ponieważ w równaniu (22) uwzględniono jedynie sygnały napięcia, nadaje się ono do wykorzystania w praktyce w zakładach produkcyjnych.

\section{Wnioski}

Powierzchnia jeziorka spawalniczego jest rzeczywiście, tak jak oczekiwano, źródłem wystarczającej ilości informacji do określenia głębokości wtopienia spoiny w spawaniu impulsowym MIG/MAG-P.

Głębokość wtopienia spoiny można określić z wystarczającą dokładnością ze zmiany ugięcia powierzchni jeziorka spawalniczego podczas fazy maksymalnego natężenia prądu.

Głębokość wtopienia spoiny można też dość dokładnie określić ze zmiany napięcia łuku w fazie maksymalnego natężenia prądu.

Ponieważ napięcie łuku jest łatwo zmierzyć w zakładach produkcyjnych, potwierdzony $w$ tej pracy związek pomiędzy głębokością wtopienia spoiny i zmianą napięcia łuku $\mathrm{w}$ fazie maksymalnego natężenia prądu dostarcza prostą, lecz przydatną w zastosowaniach produkcyjnych metodę monitorowania wtopienia spoiny.

UWAGA: w tłumaczeniu zmieniono oznaczenia:

$\mathrm{SD}=$ ds głębokość ugięcia powierzchni jeziorka spawalniCzego d

$\mathrm{PD}=\mathrm{dp}$ głębokość wtopienia $\mathrm{d}_{w}$, WFS= prędkość podawania drutu $=V_{d}$

$\mathrm{TS}=$ prędkość spawania $=\mathrm{V}_{\mathrm{s}}$

\section{Literatura}

[1] Kim, Y, S, and Eagar, T, W, 1993, Analysis of metal transfer in gas metal arc welding, Welding Journal 72: s. 269-278.

[2] Esser, W, G, and van Gompel, M, R, M, 1984, Arc control with pulsed GMA welding, Welding Journal 63: s. 26-32.

[3] Ueguri, S,, Hara, H,, and Komura, H, 1985, Study of metal transfer in pulsed GMA welding, Welding Journal 64: s. $242-250$

[4] Allum, C, J, 1985, Welding technology data: pulsed MIG weIding, Welding and Metal Fabrication 53: s. 24-30.

[5] Kovacevic, R,, Zhang, Y, M,, and Ruan, S, 1995, Sensing and control of weld pool geometry for automated GTA welding, ASME Journal of Engineering for Industry 117(2): 210-222.

[6] Chin, B, A, Madsen, N, H, and Goodling, J, S, 1983, Infrared thermography for sensing the arc welding process, Welding Journal 62: s. 227-234.
[7] Madigan, R, B,, Renwich, R, J,, Farson, D, F,, and et al, 1986, Computer-based control of full-penetration TIG welding using pool oscillation sensing, Proceedings of First International Conference on Computer Technology in Welding, The Welding Institute, London.

[8] Xiao, Y, H, 1992, Weld pool oscillation during gas tungsten arc welding, Ph,D, dissertation, Delft, The Netherlands, Delft University of Technology.

[9] Wang, Q, L, 1991, Real-time full-penetration control with arc sensor in the TIG welding of Al alloy, Proceedings of the International Conference on Joining/Welding 2000, IIW, the Netherlands.

[10] Mnich, C,, Al-Bayat, F,, Debrunner, C, and et al, 2004, In situ weld pool measurement using stereovision, ASME, Proceedings 2004, Japan - USA Symposium on Flexible Automation, Denver, Colorado. 
[11] Siores, E, 1988, Development of a realtime ultrasonic sensing system for automated and robotic welding, PhD dissertation, West London, UK, Brunel University.

[12] Groenwald, R, A,, Mathieson, T, A, Kedzior, C, T, et al, 1979 , Acoustic emission weld monitor system - data acquisition and investigation, US Army Tank-Automotive Research and Development Command Report ADA085-518.

[13] Kovacevic, R, and Zhang, Y, M, 1997, Real-time image processing for monitoring of free weld pool surface, ASME Journal of Manufacturing Science and Engineering 119(2): 161-169.

[14] Saeed, G,, and Zhang, Y, M, 2007, Weld pool surface depth measurement using calibrated camera and structured-light, Measurement Science \& Technology 18: s. 2570-2578,

[15] Song, H, S, and Zhang, Y, M, 2007, Three-dimensional reconstruction of specular surface for gas tungsten arc weld pool, Measurement Science \& Technology 18: s. 3751-3767.
[16] Song, H, S, and Zhang, Y, M, 2008, Measurement and analysis of three-dimensional specular gas tungsten arc weld pool surface, Welding Journal 87(4): s. 85-95.

[17] Zhao, D, B, 2000, Dynamic intelligent control for weld pool shape during pulsed GTAW with wire filler based on threedimension visual sensing, $\mathrm{Ph}, \mathrm{D}$, dissertation, Harbin, China, Harbin Institute of Technology (in Chinese).

[18] Yoo, C, D, and Lee, J, 3D measurement of weld pool using biprism stereo vision sensor, http://joining1.kaist.ac.kr/research/vision.htm, Seoul National University.

[19] Zhang, G, J,, Yan, Z, H,, and Wu, L, 2006, Reconstructing a three-dimensional PGMAW weld pool shape from a twodimensional visual image, Measurement Science and Technology 17(7): 1877 to 1882 .

[20] Lucas W., Smith J., Balfor C., Bertaso D., Melton G.: „Wizyjna kontrola rozmiaru jeziorka spawalniczego w czasie rzeczywistym" Przegląd Spawalnictwa nr 1/2009 s. 11-16.

\title{
Podziękowanie
}

Praca ufundowana przez amerykańską Narodową Fundację na Rzecz Nauki (NSF), dzięki grantowi CMMI-0726123 o tytule: „Measurement and Control of Dynamic Weld Pool Surface in Gas Metal Arc Welding". Badania przeprowadzono w Laboratorium Badań nad Spawalnictwem w University of Kentucky w USA.

Artykuł przedrukowano z dodatku naukowego Welding Journal vol. 89 za zgodą autora i właściciela praw autorskich Amerykańskiego Stowarzyszenia Spawalniczego AWS. Oryginał jest dostępny na stronie AWS: http://www,aws,org/wj/supplement/wj0610-117,pdf

Z języka angielskiego tłumaczyła Joanna Dobrowolska. Instytut Łączenia Metali w Krakowie dziękuje dr Katarzynie Sadowskiej-Dobrowolskiej z Instytutu Filologii Polskiej Uniwersytetu Marii Curie Skłodowskiej w Lublinie za pomoc w tłumaczeniu tekstu technicznego z USA.

\section{W następnym numerze}

\author{
Anna Pocica \\ Od parowozu do lux-torpedy. Spawanie w naprawach i produkcji taboru kolejowego. \\ Część II (z teki Jacka Lassocińskiego)
}

Paweł Cegielski, Krzysztof Skrzyniecki, Andrzej Kolasa, Paweł Kołodziejczak

Badania stabilności układu łuk - urządzenie zasilające w warunkach symulowanych zakłóceń procesu spawania metodą MAG

\section{Jacek Słania, Dariusz Kozik}

Prefabrykacja elementów ciśnieniowych kotłów typu WR

\section{Aneta Ziewiec, Janusz Stępiński, Edmund Tasak}

Mikrostruktura połączeń różnorodnych stali 17-4PH ze stopami niklu 